\title{
Radiation-Induced Spinal Glioblastoma Multiforme: A Rare Complication in the Management of Head and Neck Cancer
}

\author{
Andrew W. Ju' ${ }^{1}$, H. Ian Robins ${ }^{2,3,4}$, M. Shahriar Salamat ${ }^{5}$, Allison M. Grayev ${ }^{6}$, Steven P. Howard ${ }^{2}$ \\ ${ }^{1}$ Department of Radiation Oncology, Brody School of Medicine, East Carolina University, Greenville, NC, USA \\ ${ }^{2}$ Department of Human Oncology, School of Medicine and Public Health, University of Wisconsin, Madison, WI, USA \\ ${ }^{3}$ Department of Medicine, School of Medicine and Public Health, University of Wisconsin, Madison, WI, USA \\ ${ }^{4}$ Department of Neurology, School of Medicine and Public Health, University of Wisconsin, Madison, WI, USA \\ ${ }^{5}$ Department of Pathology, School of Medicine and Public Health, University of Wisconsin, Madison, WI, USA \\ ${ }^{6}$ Department of Radiology, School of Medicine and Public Health, University of Wisconsin, Madison, WI, USA \\ Email: hirobins@wisc.edu
}

How to cite this paper: Ju, A.W., Robins, H.I., Salamat, M.S., Grayev, A.M. and Howard, S.P. (2016) Radiation-Induced Spinal Glioblastoma Multiforme: A Rare Complication in the Management of Head and Neck Cancer. International Journal of Otolaryngology and Head \& Neck Surgery, 5, 233-241.

http://dx.doi.org/10.4236/ijohns.2016.56036

Received: October 6, 2016

Accepted: November 27, 2016

Published: November 30, 2016

Copyright $\odot 2016$ by authors and Scientific Research Publishing Inc. This work is licensed under the Creative Commons Attribution International License (CC BY 4.0).

http://creativecommons.org/licenses/by/4.0/

\section{Abstract}

Background: Radiation-induced gliomas of the spinal cord are rare late complications of spinal cord irradiation that typically occur in patients treated at younger ages. Aim: Raise awareness of radiation induced high grade gliomas with a case presentation and a review of the literature. Case Presentation: A 50-year-old male with Stage IVA squamous cell carcinoma of the oropharynx was treated with external beam radiotherapy with a complete response. Seven years later, he presented with a cervical spinal cord mass on MRI. An open biopsy was performed. Pathology revealed an intramedullary WHO grade IV astrocytoma, (i.e., glioblastoma multiforme) of the cervical spine that fulfilled the criteria for a radiation-induced malignancy. Conclusions. Review of the literature suggests that radiation-induced gliomas tend to be high grade and may occur at the periphery of an irradiated field. Radiation-induced gliomas of the spinal cord are a serious complication of radiotherapy that may occur in older patients with head and neck cancers, but are so rare that it should not affect treatment decisions.

\section{Keywords}

Central Nervous System, Spinal Cord, Glioblastoma Multiforme, Radiation Induced, Head and Neck Cancer

\section{Introduction}

Gliomas are malignancies of the central nervous system (CNS) that arise from glial 
cells. Astrocytomas are a type of glioma that predominately arises from astrocytes, and they are graded on a scale from I - IV by the World Health Organization (WHO) classification scheme. Grades III and IV are considered high grade, and grade IV astrocytomas are also known as glioblastoma (GBM). The incidence of central nervous system gliomas in the United States is 5.9 per 100,000 per year, and the incidence of GBMs is 3.1 per 100,000 per year, with a median age of diagnosis of 64 and a 5-year survival rate of $17.5 \%$ [1]. Astrocytomas of the spinal cord are one-tenth as common as astrocytomas of the brain, with an incidence of $0.8-2.5$ per 100,000 per year, and a peak age of diagnosis of $35-40$ [2]. They are typically low grade and have a good prognosis. However, $10 \%-25 \%$ of spinal cord astrocytomas are high grade, and have a poor prognosis. Although data are limited, grade IV astrocytomas (GBMs) of the spinal cord have a reported survival of $32 \%$ at 18 months [3].

After meningiomas, gliomas are the second most common radiation-induced malignancy of the CNS [4]. Radiation-induced (RI) tumors were first described by Frieben in 1908 [5]. In 1948, Cahan and colleagues established their criteria for identifying sarcomas that were associated with radiation therapy [4]. These criteria were later adapted by Liwnicz and colleagues to RI CNS malignancies, and are as follow: 1) the malignancy arises in previously irradiated fields; 2) the diagnosis of the malignancy is verified histologically; 3 ) the malignancy has a different histology than the primary malignancy; 4) the malignancy presents after a latency period that is longer than the time in which the malignancy can exist without showing overt symptoms; and 5) the patients should not have any underlying conditions that predispose them to develop malignancies [6]. RI gliomas of the spinal cord are extremely rare; only ten previously reported cases were found on our literature search [7]-[16]. Here we report the eleventh case, which is unique in that the patient is significantly older than the previously reported patients.

\section{Case Presentation}

A 50-year-old male presented with a firm, non-tender mass in his left neck. He had a 10-year history of chewing tobacco, no history of smoking, and had 2 - 3 alcoholic drinks per day. He had no other medical conditions. He had a family history of a father who died of an unknown malignancy in his eighties, an aunt who died of lung cancer, and an uncle with bladder cancer. On examination, he had a $1.5 \mathrm{~cm}$ firm area at the base of the left tongue at the junction of the inferior pole of the tonsil, and several palpable level II/III and level IV lymph nodes in the left neck. An excisional biopsy revealed invasive squamous cell carcinoma of the left tongue base with metastasis to a left deep neck node. He was ultimately determined to have Stage IVA, T1N2bM0 disease following a complete staging work-up.

The patient was treated with external beam radiotherapy using a shrinking field technique and accelerated hypofractionation. The initial large opposed lateral fields received 37.4 Gy, followed by an off-cord boost using opposed lateral beams to $50.6 \mathrm{~Gy}$. His posterior neck was boosted with $9 \mathrm{MeV}$ electrons to $52.8 \mathrm{~Gy}$. A final cone-down boost was delivered to the primary tumor and all grossly positive lymphatics to $73 \mathrm{~Gy}$. 
The bilateral supraclavicular lymph node basin received 52.8 Gy with a subsequent boost to the ipsilateral supraclavicular region to $65.4 \mathrm{~Gy}$. The dose to the spinal cord was estimated to be between 40 and $50 \mathrm{~Gy}$. The patient had a complete response, with no evidence of disease or recurrence on follow-up CT scans and chest x-rays obtained over the next 2 years. Seven years later, he developed neck pain, followed by left upper extremity weakness and left foot drop. Progression of his neurological symptoms and pain prompted an MRI of the cervical spine. This revealed an enhancing mass intrinsic to the cervical spinal cord that extended from C2 to C5-6 (Figure 1(a) and Figure 1(b)). A laminectomy and open biopsy of the lesion revealed a WHO grade IV astrocytoma (glioblastoma multiforme) containing atypical nuclei, abundant mitosis, and foci of vascular endothelial proliferation (Figure 2(a)-2(d)). Necrosis was not seen but the Ki-67 proliferative index was estimated to be between $25 \%-30 \%$. This clinical situation fulfilled Cahan's and Liwnicz's criteria and was consistent with a RI glioma. After the laminectomy, the patient received 50 Gy of palliative re-irradiation with LINAC based radiotherapy ( $2 \mathrm{GY} /$ day for 25 treatments over 5 weeks). In spite of initial clinical and radiological improvement, he subsequently progressed at 3 months, and succumbed to his malignancy 7 months after his diagnosis of a spinal cord GBM.

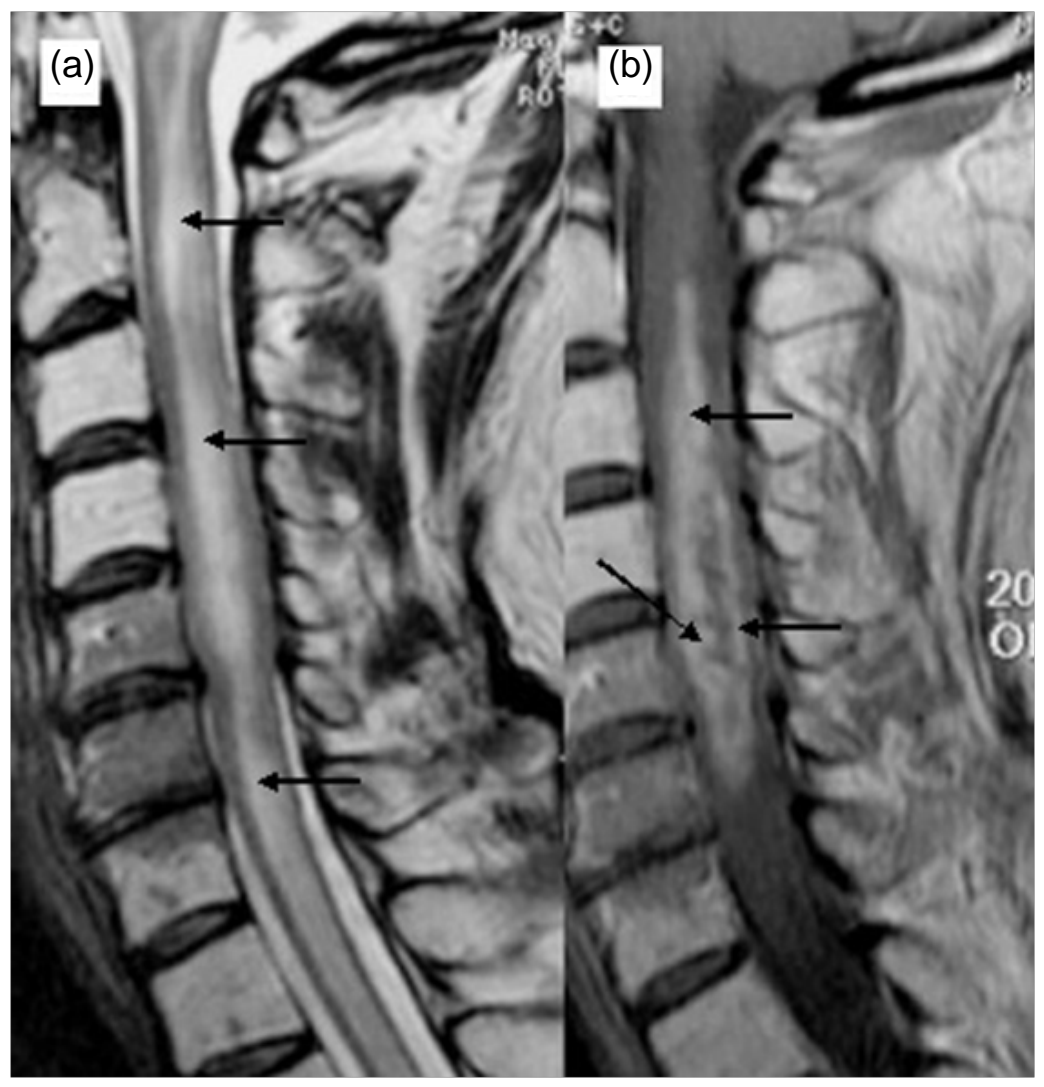

Figure 1. (a) Sagittal T2 image demonstrating extensive cord edema extending from the skull base throughout the cervical spine. Marked expansion of the cord is noted; (b) Sagittal T1 image after contrast demonstrating peripheral enhancement in the region of greatest cord expansion. 


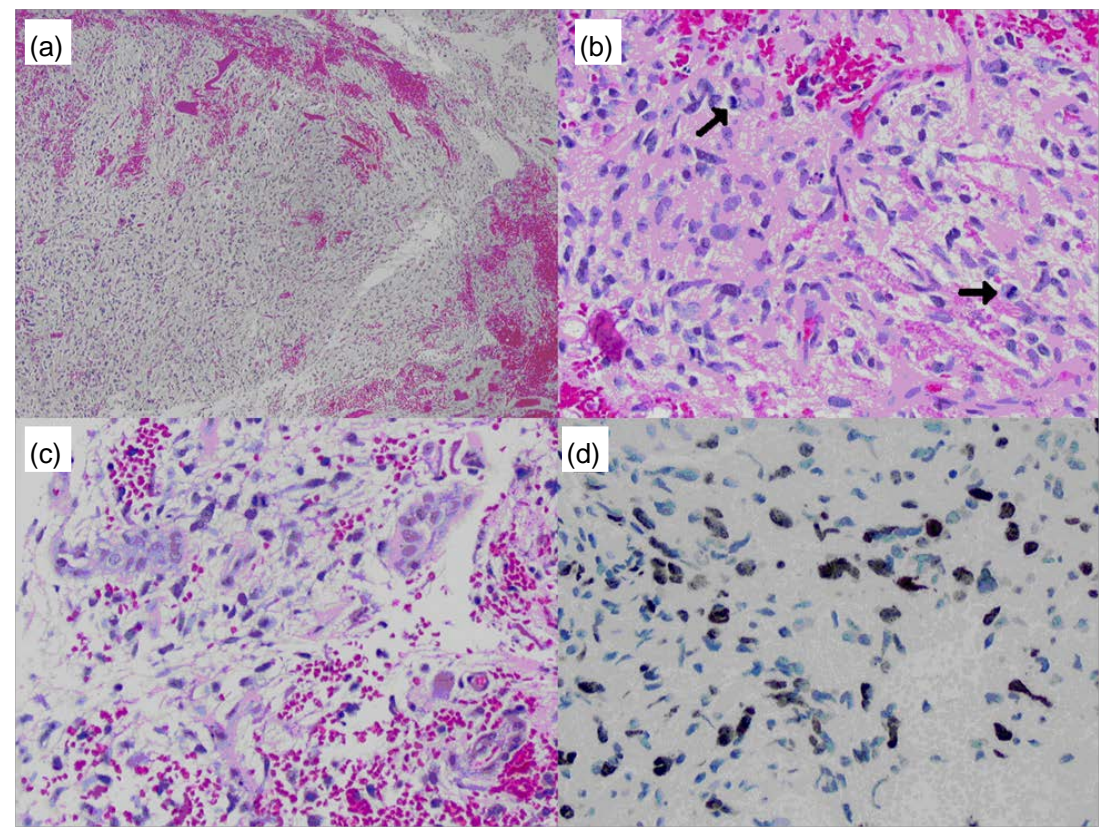

Figure 2. (a) $\mathrm{H} \& \mathrm{E}$ stained section of tumor reveals an infiltrating neoplasm (4x original magnification); (b) At higher magnification (20x) Tumor cells reveal astrocytic features, a fibrilary background, nuclear atypia and frequent mitotic activities (arrow heads); (c) Other areas reveal vascular endothelial proliferation (20x); (d) The Ki-67 proliferative index is estimated to be between $25 \%-30 \%(20 \times)$.

\section{Discussion}

It is possible that our patient's spinal cord GBM was a second spontaneous malignancy that was unrelated to his prior radiotherapy, since spontaneous spinal cord gliomas tend to occur in adults, and RI gliomas occur more commonly in younger patients [17] [18]. However, the patient's GBM fits Cahan and Liwnicz's criteria for a RI malignancy of the CNS: 1) the patient's cervical spinal cord was included in the originally irradiated fields; 2) the histology of his tumor was verified by excisional biopsy; 3 ) the histology was different from the initial squamous cell carcinoma; 4) GBMs of the spinal cord produce symptoms over a period of weeks to months, and this malignancy presented itself after a latency period of 7 years; and 5) the patient has no evidence of any disorder that predisposes him to the development of malignancies. In addition to satisfying these criteria, the incidence of spontaneous spinal cord astrocytomas is 0.8 to 2.5 per 100,000 per year [2], and $75 \%-90 \%$ of these astrocytomas are low-grade [17], which gives a $1 / 10,000$ to a $1 / 100,000$ probability that our patient would develop a spontaneous highgrade astrocytoma of the spinal cord within 15 years of developing his primary squamous cell carcinoma. In comparison, it is estimated that the lifetime risk of developing a RI brain tumor after cranial irradiation is $1 \%$ - 3\% [19] [20] [21]. Furthermore, risk factors such as tobacco and alcohol use that make second malignancies more common in head and neck cancer patients are not established risk factors for development of gliomas. These arguments make it likely that the patient's spinal cord GBM is a radiation-induced tumor, although no method exists to determine this with certainty. 
As long-term patient survival increases with improved treatment technology for head and neck cancer patients, late toxicities such as RI malignancies may become an increasing concern. Radiation-induced sarcomas, thyroid carcinomas, skin cancers, squamous cell carcinomas, and salivary gland tumors have been previously reported after radiotherapy for head and neck cancers [22] [23]. Our patient is the second one reported to develop a radiation-induced glioma of the spinal cord after radiotherapy for head and neck cancer. The other patient, reported by Yeung and colleagues, developed a cervical spinal cord GBM after being treated when she was 28 years old for a nasopharyngeal carcinoma at a total dose of $86 \mathrm{~Gy}$, although the dose at the site of her recurrence in the cervical spinal cord was most likely lower [15]. Our patient was estimated to have received between 40 - 50 Gy to the cervical spinal cord. This case illustrates the point that normal tissues in the periphery of an irradiated field that receive a low or moderate dose of radiation, such as the spinal cord in the treatment of head and neck cancers, are still at risk for developing RI tumors. A direct relationship between radiation dose and the incidence of $\mathrm{RI}$ malignancies is well documented in the range of 0.1 to $2.5 \mathrm{~Gy}$ in atomic bomb survivors [24]. At higher doses, this dose-incidence relationship is uncertain, and the incidence may plateau or decrease as the dose increases beyond 3 Gy [25]. RI malignancies may become an increasing concern in the future as intensity-modulated radiotherapy increases the volume of normal tissue exposed to potentially carcinogenic radiation during treatment [25]. This applies in particular to RI gliomas, which tend to occur in areas receiving a lower dose of radiation, compared to RI sarcomas, which generally occur in the regions of highest dose [26]. Intracranial RI GBMs have been reported in patients treated to a dose as low as $3 \mathrm{~Gy}$ for tinea capitis [6] [18].

To our knowledge, the present case is the oldest known patient to develop a RI GBM of the spinal cord. This illustrates that older patients, who are at higher risk for developing cancers of the head and neck, are still at risk for developing RI malignancies, despite the fact that $60 \%$ of intracranial RI malignancies occur in patients treated as children or young adults [6]. This higher incidence in younger patients may be due to an intrinsic sensitivity to developing RI malignancies [27] [28]. However, RI gliomas of the brain are not uncommon after radiotherapy for pituitary adenomas, which generally occur in an older patient population. Nine out of 14 patients in one review, and 4 out of 4 patients in another who developed intracranial RI gliomas after radiotherapy were over the age of 35 [18] [19]. Two out of the 3 patients were reported to develop intracranial RI GBMs after stereotactic radiosurgery for pituitary adenomas were over 35 years old [27], and one patient was 63 years old at the time of radiosurgery [30].

RI gliomas of the CNS tend to be higher in grade than those that occur spontaneously. In a review of the literature, Liwnicz and colleagues found that of 24 RI CNS gliomas, 19 were either anaplastic astrocytomas or glioblastomas [6]. This appears to be the case for RI gliomas of the spinal cord as well, with 9 high-grade gliomas out of the 11 total cases (Table 1). Spontaneous spinal cord astrocytomas are most often low grade, and typically have a good prognosis, with an overall 5-year survival rate of between 
Table 1. Published cases of radiation-induced spinal cord gliomas.

\begin{tabular}{|c|c|c|c|c|c|c|c|c|}
\hline Author and Year & Primary disease & $\begin{array}{l}\text { Age at } \\
\text { irradiation } \\
\text { and Gender }\end{array}$ & $\begin{array}{l}\text { Maximum } \\
\text { radiation } \\
\text { dose }(G y)\end{array}$ & $\begin{array}{l}\text { Estimated spinal } \\
\text { cord dose at site of } \\
\text { recurrence }(\mathrm{Gy})\end{array}$ & $\begin{array}{l}\text { Latency } \\
\text { period } \\
\text { (years) }\end{array}$ & Tumor type & $\begin{array}{l}\text { Tumor location in } \\
\text { spine }\end{array}$ & $\begin{array}{l}\text { Follow-up } \\
\text { period }\end{array}$ \\
\hline $\begin{array}{l}\text { Clifton et al., } \\
1980\end{array}$ & Hodgkin's disease & $21 \mathrm{M}$ & 50 & 49.69 & 6 & GBM & Cervico-thoracic & $10 \mathrm{wks}^{*}$ \\
\hline Steinbock, 1980 & $\begin{array}{l}\text { Pulmonary } \\
\text { tuberculosis }\end{array}$ & $20-23 \mathrm{~F}$ & $\begin{array}{l}\text { Unable to } \\
\text { calculate }\end{array}$ & Unable to calculate & 25 & $\begin{array}{l}\text { Low-grade } \\
\text { astrocytoma }\end{array}$ & Cervico-thoracic & 27 months \\
\hline $\begin{array}{l}\text { Marus et al., } \\
\quad 1986\end{array}$ & Thyroid cancer & $19 \mathrm{~F}$ & 58 & $45-55$ & 23 & $\begin{array}{c}\text { Anaplastic } \\
\text { astrocytoma }\end{array}$ & Upper thoracic & 20 months ${ }^{*}$ \\
\hline Bazan et al., 1990 & Hodgkin's disease & $19 \mathrm{M}$ & 40 & Not calculated & 7 & $\begin{array}{l}\text { Grade II - III } \\
\text { astrocytoma }\end{array}$ & Cervical & 6 months \\
\hline $\begin{array}{c}\text { Grabb et al., } \\
1996\end{array}$ & $\begin{array}{l}\text { Medullomyo } \\
\text { blastoma }\end{array}$ & $3 \mathrm{~F}$ & 54.4 & 30.0 & 17 & $\begin{array}{c}\text { Anaplastic } \\
\text { astrocytoma }\end{array}$ & Cervical & 4 months ${ }^{\star}$ \\
\hline $\begin{array}{l}\text { Yeung et al., } \\
2006\end{array}$ & $\begin{array}{l}\text { Nasopharyngeal } \\
\text { carcinoma }\end{array}$ & $28 \mathrm{~F}$ & 86 & Not calculated & 7 & GBM & Cervical & 8 months \\
\hline Ng et al., 2007 & Hodgkin's disease & $23 \mathrm{M}$ & 30.60 & Not calculated & 3 & GBM & Thoracic & $\begin{array}{l}\text { Unknown, } \\
\text { weeks }^{*}\end{array}$ \\
\hline Ahn \& Kim 2012 & $\begin{array}{c}\text { Nasopharyngeal } \\
\text { Rhabdomyosarcoma }\end{array}$ & $4 \mathrm{~F}$ & 45 & Not calculated & 13 & GBM & cervical & 8 months \\
\hline $\begin{array}{c}\text { Kawanabe et al. } \\
2012\end{array}$ & $\begin{array}{l}\text { Testicular } \\
\text { seminoma }\end{array}$ & $18 \mathrm{M}$ & 30.6 & Not Calculated & 37 & $\begin{array}{c}\text { Anaplastic } \\
\text { astrocytoma }\end{array}$ & thoracic & $9 \mathrm{M}^{*}$ \\
\hline Present case & $\begin{array}{l}\text { Squamous cell } \\
\text { carcinoma of the } \\
\text { tongue base }\end{array}$ & $50 \mathrm{M}$ & 73 & $40-50$ & 7 & GBM & Cervical & 7 months $^{*}$ \\
\hline
\end{tabular}

*patient deceased at end of follow-up.

$70 \%-90 \%$ [17]. The survival rate of RI gliomas appears to be worse, which may correspond with their higher grade [15]. Of the 5 patient's in Table 1 with RI GBMs of the spinal cord, none survived longer than 8 months, compared to the median survival of 10 - 12 months in patients with spontaneous spinal cord GBMs [31]. Although the differences in grade and prognosis between RI gliomas and spontaneous gliomas of the CNS suggest a difference in biological behavior, studies have been unable to show differences in the histological characteristics or the specific mutation patterns [32].

\section{Conclusion}

Radiation-induced gliomas of the spinal cord are a serious and quite likely fatal complication of the radiotherapy used in the management of head and neck cancers. However, the incidence is exceedingly low such that fear of this complication should not affect treatment decisions. Although the clinical experience is limited, RI gliomas tend to be higher in grade and carry a worse prognosis than spontaneous gliomas of the spinal cord. Our case illustrates that RI spinal cord gliomas may occur in patients who are treated at an older age. In addition, it appears that RI gliomas occur at the periphery of 
the treatment fields or in the regions exposed to lower doses of radiation. Our observation may have increasing importance in the future as current treatment modalities target tumor more precisely while increasing the overall volume of normal tissue exposed to low and moderate doses of potentially carcinogenic radiation. RI malignancies may also become an increasing concern as long-term patient survival increases with improved cancer treatments.

\section{Acknowledgements}

Support provided by the Kathleen Reader Neuro-Oncology Fund.

\section{References}

[1] Central Brain Tumor Registry of the United States 2008 Statistical Report: Primary Brain Tumors in the United States. http://www.cbtrus.org/

[2] Alter, M. (1975) Tumours of the Spine and Spinal Cord. In: Klawans, H.L., Ed., American Elsevier, Amsterdam, 1-22.

[3] Ciappetta, P., Salvati, M., Capoccia, G., Artico, M., Raco, A. and Fortuna, A. (1991) Spinal Glioblastomas: Report of Seven Cases and Review of the Literature. Neurosurgery, 28, 302306. https://doi.org/10.1227/00006123-199102000-00022

[4] Cahan, W.G., Woodard, H.Q., et al. (1948) Sarcoma Arising in Irradiated Bone; Report of 11 Cases. Cancer, 1, 3-29. https://doi.org/10.1002/1097-0142(194805)1:1<3::AID-CNCR2820010103>3.0.CO;2-7

[5] Frieben, H. (1902) Demonstration eines Cancroid des rechten Hendruckens, das sich nach langdauernder Einwirkung von Roentgenstrahlen entwickelt hatte Fortshce. Rontgenstr, 6, 106-111.

[6] Liwnicz, B.H., Berger, T.S., Liwnicz, R.G. and Aron, B.S. (1985) Radiation-Associated Gliomas: A Report of Four Cases and Analysis of Postradiation Tumors of the Central Nervous System. Neurosurgery, 17, 436-445. https://doi.org/10.1227/00006123-198509000-00007

[7] Ahn, S.J. and Kim, I.O. (2012) Spinal Cord Glioblastoma Induced by Radiation Therapy of Nasopharyngeal Rhabdomyosarcoma with MRI Findings: Case Report. Korean Journal of Radiology, 13, 652-657. https://doi.org/10.3348/kjr.2012.13.5.652

[8] Bazan, C., New, P.Z. and Kagan-Hallet, K.S. (1990) MRI of Radiation Induced Spinal Cord Glioma. Neuroradiology, 32, 331-333. https://doi.org/10.1007/BF00593057

[9] Clifton, M.D., Amromin, G.D., Perry, M.C., Abadir, R., Watts, C. and Levy, N. (1980) Spinal Cord Glioma Following Irradiation for Hodgkin's Disease. Cancer, 45, 2051-2055. https://doi.org/10.1002/1097-0142(19800415)45:8<2051::AID-CNCR2820450811>3.0.CO;2$\underline{3}$

[10] Grabb, P.A., Kelly, D.R., Fulmer, B.B. and Palmer, C. (1996) Radiation-Induced Glioma of the Spinal Cord. Pediatric Neurosurgery, 25, 214-219. https://doi.org/10.1159/000121127

[11] Marus, G., Levin, C.V. and Rutherfoord, G.S. (1986) Malignant Glioma Following Radiotherapy for Unrelated Primary Tumors. Cancer, 58, 886-894. https://doi.org/10.1002/1097-0142(19860815)58:4<886::AID-CNCR2820580415>3.0.CO;2B

[12] Ng, C., Fairhall, J., Rathmalgoda, C., Stening, W. and Smee, R. (2007) Spinal Cord Glioblastoma Multiforme Induced by Radiation after Treatment for Hodgkin Disease. Case Re- 
port. Journal of Neurosurgery: Spine, 6, 364-367. https://doi.org/10.3171/spi.2007.6.4.14

[13] Riffaud, L., Bernard, M., Lesimple, T. and Morandi, X. (2006) Radiation-Induced Spinal Cord Glioma Subsequent to Treatment of Hodgkin's Disease: Case Report and Review. Journal of Neuro-Oncology, 76, 207-211. https://doi.org/10.1007/s11060-005-5532-y

[14] Steinbok, P. (1980) Spinal Cord Glioma after Multiple Fluoroscopies during Artificial Pneumothorax Treatment of Pulmonary Tuberculosis: Case Report. Journal of Neurosurgery, 52, 838-841. https://doi.org/10.3171/jns.1980.52.6.0838

[15] Yeung, Y.F., Wong, G.K., Zhu, X.L., Ma, B.B., Hk, N.G. and Poon, W.S. (2006) Radiation-Induced Spinal Glioblastoma Multiforme. Acta Oncologica, 45, 87-90. https://doi.org/10.1080/02841860500341124

[16] Kawanabe, Y., Sawada, M., Yukawa, H., Ueda, S., Sasaki, N., Koizumi, T., Kihara, S. and Hoshimaru, M. (2012) Radiation-Induced Spinal Cord Anaplastic Astrocytoma Subsequent to Radiotherapy for Testicular Seminoma. Neurologia Medico-Chirurgica, 52, 675-678. https://doi.org/10.2176/nmc.52.675

[17] Henson, J.W. (2001) Spinal Cord Gliomas. Current Opinion in Neurology, 14, 679-682. https://doi.org/10.1097/00019052-200112000-00001

[18] Salvati, M., Frati, A., Russo, N., Caroli, E., Polli, F.M., Minniti, G. and Delfini, R. (2003) Radiation-Induced Gliomas: Report of 10 Cases and Review of the Literature. Surgical Neurology, 60, 60-67. https://doi.org/10.1016/S0090-3019(03)00137-X

[19] Al-Mefty, O., Al-Rodhan, N.R., Phillips, R.L., El-Senossi, M. and Fox, J.L. (1987) Factors Affecting Survival of Children with Malignant Gliomas. Neurosurgery, 20, 416-420. https://doi.org/10.1227/00006123-198703000-00010

[20] Anderson, J.R. and Treip, C.S. (1984) Radiation-Induced Intracranial Neoplasms. A Report of Three Possible Cases. Cancer, 53, 426-429. https://doi.org/10.1002/1097-0142(19840201)53:3<426::AID-CNCR2820530310>3.0.CO;2-L

[21] Tsang, R.W., Laperriere, N.J., Simpson, W.J., Brierley, J., Panzarella, T. and Smyth, H.S. (1993) Glioma Arising after Radiation Therapy for Pituitary Adenoma. A Report of Four Patients and Estimation of Risk. Cancer, 72, 2227-2233. https://doi.org/10.1002/1097-0142(19931001)72:7<2227::AID-CNCR2820720727>3.0.CO;2I

[22] Sale, K.A., Wallace, D.I., Girod, D.A. and Tsue, T.T. (2004) Radiation-Induced Malignancy of the Head and Neck. Otolaryngology_Head and Neck Surgery, 131, 643-645. https://doi.org/10.1016/j.otohns.2004.05.012

[23] Van der Laan, B.F., Baris, G., Gregor, R.T., Hilgers, F.J. and Balm, A.J. (1995) Radiation-Induced Tumours of the Head and Neck. Journal of Laryngology and Otology, 109, 346-349. https://doi.org/10.1017/S0022215100130117

[24] Preston, D.L., Ron, E., Tokuoka, S., Funamoto, S., Nishi, N., Soda, M., Mabuchi, K. and Kodama, K. (2007) Solid Cancer Incidence in Atomic Bomb Survivors: 1958-1998. Radiation Research, 168, 1-64. https://doi.org/10.1667/RR0763.1

[25] Hall, E.J. (2006) Intensity-Modulated Radiation Therapy, Protons, and the Risk of Second Cancers. International Journal of Radiation Oncology Biology Physics, 65, 1-7. https://doi.org/10.1016/j.ijrobp.2006.01.027

[26] Kaschten, B., Flandroy, P., Reznik, M., Hainaut, H. and Stevenaert, A. (1995) RadiationInduced Gliosarcoma. Case Report and Review of the Literature. Journal of Neurosurgery, 83, 154-162. https://doi.org/10.3171/jns.1995.83.1.0154

[27] Loeffler, J.S., Niemierko, A. and Chapman, P.H. (2003) Second Tumors after Radiosurgery: Tip of the Iceberg or a Bump in the Road? Neurosurgery, 52, 1436-1440. 


\section{https://doi.org/10.1227/01.NEU.0000064809.59806.E8}

[28] Bhatia, S., Robison, L.L., Oberlin, O., Greenberg, M., Bunin, G., Fossati-Bellani, F. and Meadows, A.T. (1996) Breast Cancer and Other Second Neoplasms after Childhood Hodgkin's Disease. New England Journal of Medicine, 334, 745-751. https://doi.org/10.1056/NEJM199603213341201

[29] Minniti, G., Traish, D., Ashley, S., Gonsalves, A. and Brada, M. (2005) Risk of Second Brain Tumor after Conservative Surgery and Radiotherapy for Pituitary Adenoma: Update after an Additional 10 Years. Journal of Clinical Endocrinology and Metabolism, 90, 800-804. https://doi.org/10.1210/jc.2004-1152

[30] Yu, J.S., Yong, W.H., Wilson, D. and Black, K.L. (2000) Glioblastoma Induction after Radiosurgery for Meningioma. Lancet, 356, 1576-1577. https://doi.org/10.1016/S0140-6736(00)03134-2

[31] Santi, M., Mena, H., Wong, K., Koeller, K., Olsen, C. and Rushing, E.J. (2003) Spinal Cord Malignant Astrocytomas. Clinicopathologic Features in 36 Cases. Cancer, 98, 554-561. https://doi.org/10.1002/cncr.11514

[32] Brat, D.J., James, C.D., Jedlicka, A.E., Connolly, D.C., Chang, E., Castellani, R.J., Schmid, M., Schiller, M., Carson, D.A. and Burger, P.C. (1999) Molecular Genetic Alterations in Radiation-Induced Astrocytomas. American Journal of Pathology, 154, 1431-1438. https://doi.org/10.1016/S0002-9440(10)65397-7

\section{Submit or recommend next manuscript to SCIRP and we will provide best service} for you:

Accepting pre-submission inquiries through Email, Facebook, LinkedIn, Twitter, etc. A wide selection of journals (inclusive of 9 subjects, more than 200 journals)

Providing 24-hour high-quality service

User-friendly online submission system

Fair and swift peer-review system

Efficient typesetting and proofreading procedure

Display of the result of downloads and visits, as well as the number of cited articles Maximum dissemination of your research work

Submit your manuscript at: http://papersubmission.scirp.org/

Or contact ijohns@scirp.org 